\title{
CONVERSION OF ATRIAL FIBRILLATION TO SINUS RHYTHM WITH AMIODARONE
}

\author{
A. Lema Santos, Ana M. Aleixo, Jorge Landeiro, A. Sales Luis
}

\begin{abstract}
Department of Medicine I, Faculty of Medical Sciences, Egas Moniz Hospital, Lisbon; and Vila Franca District Hospital, Vila Franca de Xira
\end{abstract}

\begin{abstract}
SUMMARY
In order to acess the efficacy of amiodarone as an atrial fibrillation cardioverter a trial was performed with 88 individual experiments on 80 patients with stable atrial fibrillation secondary to various cardiopathies. Eighty six per cent of the treated episodes sucessfully converted to sinus rhythm usually between the $3 \mathrm{rd}$ and 5 th days of treatment, and the rate of reversion one year later was very low $(72 \%$ of controled patients were on sinus rhythm). Failure to convert was related to enlargement of one or both atria. Most important reversible side effects such as corneal micro-deposits, hormonal disturbances and AV and intraventricular conduction defects were discussed. Comparing results with DC electrical countershock and amiodarone to obtain conversion of atrial fibrillation to sinus rhythm, it is possible to conclude equal efficacy and innocuity, being the chemical use easier by its simple requirements in contrast with the complex procedure inherent to the former.
\end{abstract}

Attempted conversion of chronic atrial fibrillation remained most controversial previously to the use of electrical DC countershock. Quinidine used to be the best drug for this purpose and successful treatment with it has been attained, according to some reports, $70 \%$ of treated cases (Holzman 1951).

Against the quinidine conversion it was argued that its serum levels had to be very high, just about the toxic zone; that a great percentage of important side effects was frequently recorded; and that a complex procedure to monitorize the treatment was needed.

A complete change was observed after the utilization of electrical DC countershock to converte to sinus rhythm. After Lown's paper (1962), generalized application of this technique allowed a well defined knowledge of its results, innocuity, haemodynamic advantages and precise indications.

Eighty five to $95 \%$ of treated patients (Luis et al. 1963, Coelho et al. 1964) have ben converted to sinus rhythm without significant complications. Symptomatic and haemodynamic immediate results were impressive enough to excite patients and doctors. As the only important bias a high rate of reversion to atrial fibrillation was recorded. So, after 1 and 2 years, respectivelly 35 and $20 \%$ of the patients reverted and prophylactic administration of quinidine did not change the figures (Luis 1973).

Received: 16 January 1979 
Even so, conversion of atrial fibrillation is now formally indicated whenever a significant symptomatic and haemodynamic disturbance is present.

In order to maintain the sinus rhythm after cardioversion, trials with antiarrhytmic drugs have been performed. Besides quinidine, beta-adrenergic blockers, verapamil and diisopyramide were used. As the electrical DC countershock needs complex procedures such as sophisticated machinery, narco-analgesy and monitorized survey for some hours to be executed, attempts to return to chemical conversion continued, looking for an easier way to get the very same results with a similar innocuity.

Meanwhile Olson et al (1973), using suction electrodes, were able to show that conversion and reversion from and to atrial fibrillation were directly related with the atrial monophasic action poiential' (MAP) duration, being larger in sinus rhythm and shorter in atrial fibrillation. Drugs able to enlarge the MAP' duration (Vaugham Williams' group III), would be physiologically indicated. Amiodarone is the paradigm drug of this group. A hundred times more potent than Visgano as an anti-angina drug, it has been used as that since some 20 years ago, but only on late sixty's Amiodarone was recognized as a good antiarrhytmic drug.

Our aim in the present study was to characterize the clinical efficacy of amiodarone, as a cardioverter.

\section{MATERIALS AND ME'THODS}

In the present paper the efficacy of amiodarone to convert atrial fibrillation has ben analysed on the basis of an experiment performed on 80 patients. Four of these had done therapy twice while another one has 4 repeated therapeutic courses, thus the total amount being of 88 individual experiments.

The evaluated patients ranged from 18 up to 91 years of age, with the highest peaks on the $3 \mathrm{rd}$, 5 th and 6 th decades of life. The different etiologies of atrial fibrillation have been resumed on Table 1, where the enormous importance of hypertensive and arteriosclerotic cardiac lesions is emphasized, although $1 / 4$ of the patients had some valvulopathy at the origin of their atrial fibrillation and subjacent disease could not be discovered in other 7 patients (idiopathic fibrillation).

\section{TABLE I}

Etiologies. 80 patients with Atrial Fibrillation

$\begin{array}{lr}\text { HYPERTENSIVE HEART DISEASE } & 26 \\ \text { ISCHEMIC HEART DISEASE } & 31 \\ \text { VALVULAR HEART DISEASES } & 13 \\ \text { CARDIOPATHIES } & 3 \\ \text { WOLF - PARKINSON - WHITE SYNDROME } & 3 \\ \text { WITHOUT CARDIOPATHY } & 4\end{array}$

Patients with overt hyperthyroidism, complete AV block or junctional rhythm have been ruled out of this experiment. All the same, patients who had had stabilised atrial fibrillation for over two years or less than 12 hours, have also not been accepted.

It should be noted, however, that $80 \%$ of the cases had stabilised atrial fibrillation for over 48 hours and more than half had it for over two weeks. 
Patients have been treated with initial doses of 200 up to $400 \mathrm{mg}$ of amiodarone and thereon with daily doses of 600 up to $800 \mathrm{mg}$ for as long as required to complete cardioversion, the therapy being given up if results were not achieved within a month. No other antiarrhytmic drug has ever been associated. Frequently, in case of cardiac failure, diuretics and digitalis have been simultaneously administered.

Ambulatory patients were daily, or in alternated days, observed and results have been conveniently plotted out, as well as side effects.

As soon as cardioversion was achieved or after a month of therapy the dose was reduced, in most cases, to $400 \mathrm{mg}$ daily, being further reduced 2 to 4 weeks later for a dose as low as $200 \mathrm{mg}$ a day. Beyond the 3rd month the daily dose was ommited once or twice a week according to the degree of bradycardia presented by the patient.

Only ten patients have kept daily maintenance doses higher than these after the $3 \mathrm{rd}$ month (in the range of 300 to $400 \mathrm{mg}$ per day).

\section{RESULTS}

Seventy five out of the 88 experiments have led to return to sinus rhythm, that means, the chemical cardioversion has been successful in about $86 \%$ of the cases.

In more than $50 \%$ of the patients, cardioversion has been achieved between the 3 rd and 5 th day with an average of about 4 days and the extreme values of only a few hours, in a single patient (according to his own information) and 28 days, have been reported.

One patient had been submitted in vain to a trial on electrical cardioversion and later converted to sinus rhythm with amiodarone, while another patient with rheumatic heart valve disease previously twice submitted to treatment with electrical DC countershock, who had a positive response of short duration on the first trial and no response at all on the second, was steadily converted with amiodarone, having held the sinus rhythm for 4 months with maintenance doses of $200 \mathrm{mg}$ a week. After this period there was return to atrial fibrillation and on a second attempt amiodarone has been ineffective.

Another patient with arteriosclerotic cardiopathy responded positively to daily doses of $600 \mathrm{mg}$ of amiodarone, but returned too easily to fibrillation when the dose was reduced to $400 \mathrm{mg}$ a day. Good results have been thrice achieved when increasing the dose of amiodarone, but fibrillation always returned when it was again reduced. On the $4 \mathrm{rd}$ attempt the dose of $600 \mathrm{mg}$ has been kept for a month, though the patient had been on sinus rhythm from the 2 nd day on, and only then maintenance therapy with 400 and, later, $200 \mathrm{mg}$ of amiodarone, has been instituted. One year later the patient was still kept in sinus rhythm.

Another patient with Wolf-Parkinson-White syndrome twice responded positively to therapy, but the effective dose of amiodarone to maintain sinus rhythm was $400 \mathrm{mg}$ per day.

Nine out of twelve patients, who did not convert to sinus rhythm, exhibited, on $\mathrm{X}$-ray examination, large right or left atria, whereas in the other 3 patients the atrial silhouette showed no abnormality. Although it was not possible to find out any relationship between the failure of treatment and any particular subjacent disease the percentage of rheumatic heart valve disease ( 7 out of 12 non-defibrillated' patients) is a clue to the importance of rheumatic heart lesions as the etiology of this situation. 


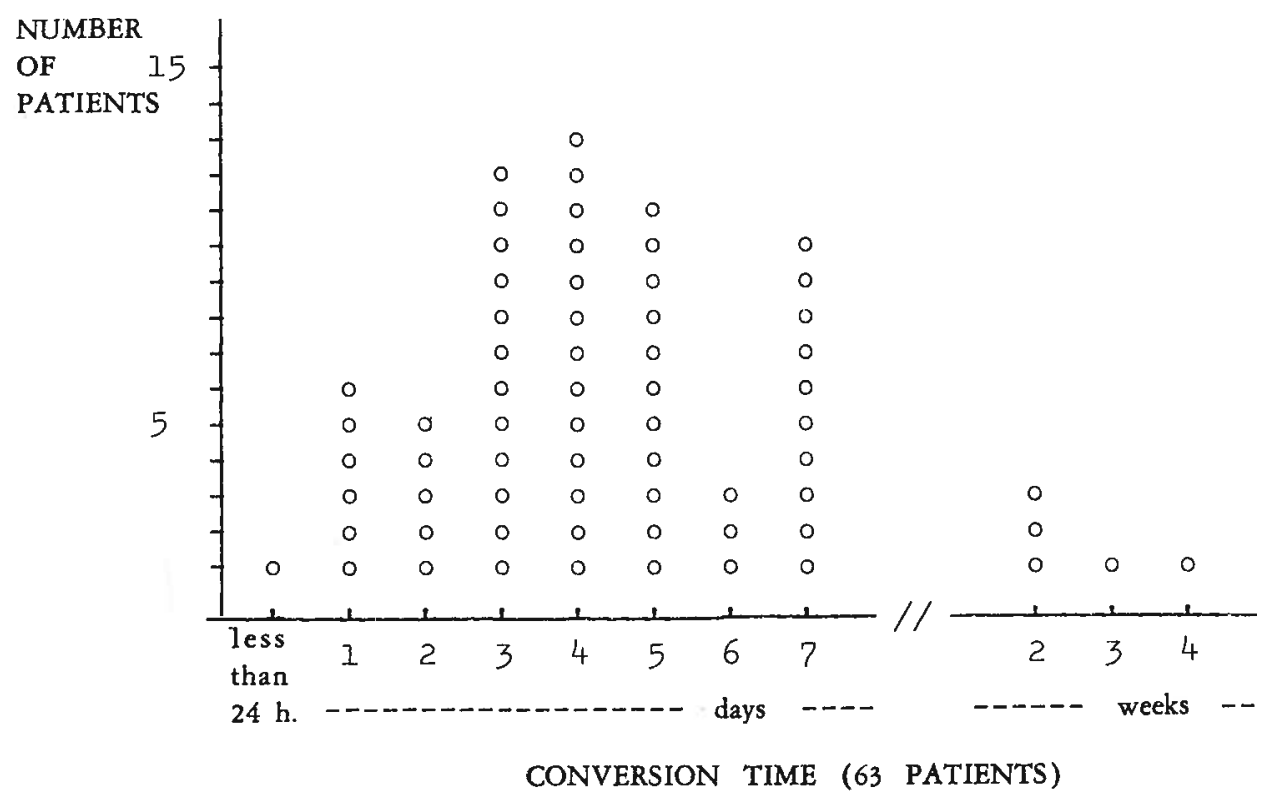

Fig. 1 - Distribution of patients acording to the conversion tume

Whenever possible, cardiac rhythm has been evaluated, one year after therapy, in those patients who had been sucessfully converted and were then taking maintenance doses of amiodarone. It was found that 32 out of 44 patients ( $72 \%$ ) in these circumstances were still in sinus rhythm a year later.

Therapy involved no special problems and gastric disconfort was merely a fleeting accident which did not connote any gap in the subsequent course of treatment.

Unimportant side effects related to hypothyroidism have been detected in 2 patients after several months of maintenance therapy but promptly disappeared when the drug was withdrawn.

Any evidence of hyperthyroidism or cutaneous lesion enhanced by amiodarone has not been reported.

Bradycardia has been a constant finding and always preceded cardioversion. In a single patient AV Wenckback' block has been detected, but this problem was solved when amiodarone was discontinued.

No case of embolism has been reported though only valvular patients have been subjected to anticoagulants.

Ocular side effects were merely asymptomatic although in one patient diminished visual acuity was reported.

Patients have been periodically assessed, whenever possible, with ophthalmologic control and this has been done in any case when the maintenance therapy lasted for over months with more than $400 \mathrm{mg}$ of amiodarone per day. In these patients, corneal micro deposits have been constantly detected (type I and II) but complete reversion was accomplished within 2 months when amiodarone was discontinued (Fig. 2). 


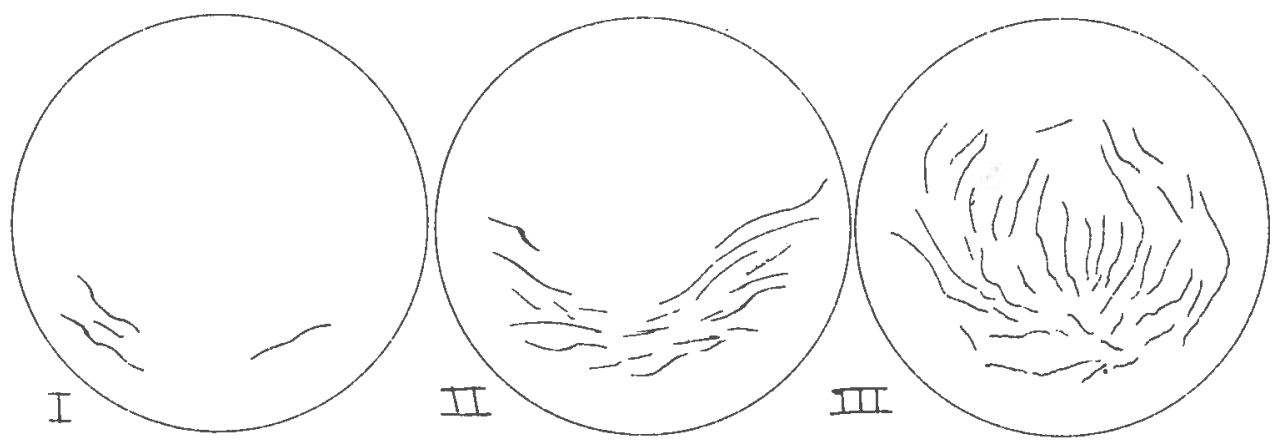

Fig. 2-Corneal micro-deposits (scbeme)

Frequent electrocardiographic alterations, which had not any effect on therapy, included, besides bradycardia, a longer QT interval, digitalis like ST depression and rounded $T$ waves, often with a notched ascending branch or apex (bifid $T$ waves).

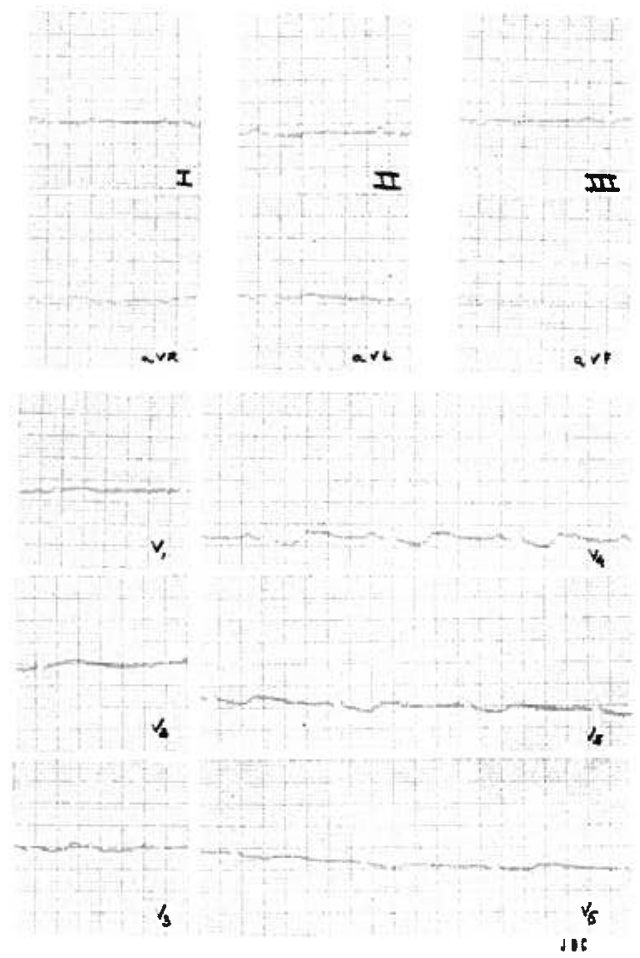

Fig. 3-EKG of a patient with amiodarone impregnation. Note the bradicardia, the ST - segment depression. the enlarged $Q-T$ and the bifid $T$-wave 


\section{DISCUSSION}

Vartesaeger et al (1971) have evaluated the efficacy of amiodarone in the treatment of atrial fibrillation by studying 20 patients with paroxismal processes and 5 other patients with long-standing disease. As a result of this experiment the authors have ascertained the efficacy of amiodarone as a prophylactic measure, since 15 patients out of the lst group have converted to sinus rhythm while no patient belonging to the 2nd group could be sucessfully converted. The latter result stands out against the use of amiodarone as a curative procedure.

Lefevre and Cramar (1975), who have treated 14 patients with amiodarone, reported a rate of cardioversion of only $50 \%$ while Rosenbaum et al (1976) on a study on 30 patients with atrial fibrillation or flutter have reported 29 sucessful cardiovetsions $(96 \%)$.

Our study has been performed upon a larger number of patients and was restricted to stabilised atrial fibrillation. Twelve hours and two years of process evolution have also been imposed as the arbitrary boundary beyond which patients were not accepted. ruling out this way those paroxismal entities bound to spontaneous reversion and those where long standing atrial fibrillation resulted in morphologic lesions leading to shunts among the cardiac fibrils and failure of conversion. Cases where the use of amiodarone could bring about untoward side effects such as AV block, bradycardia or hyperthyroidism have also been ruled out.

On our own study we came to the conclusion that results accomplished have been similar to those reported for electrical cardioversion (86\% VS $89 \%$ ) and that the lapse of time required for chemical cardioversion -3 to 5 days - was not significant on its own, and could be partially counteracted by pre-existent bradycardia.

The excellent low rate of reversion found a year later could be well explained by the continuous intake of amiodarone at a maintenance dose and is certainly much better than that found after electrical cardioversion with or without long course maintenance doses of quinidine. This comparison has also led to the conclusion that amiodarone was a more effective prophylactic drug than quinidine in order to avoid relapsing back to complete arrhythmia.

As afore mentioned concerning external electric shock, a great refractoriness to therapy has ben found in patients with rheumatic heart valve disease.

Although data have not been quite conclusive, there was a tendency to failure of therapy when any of the atria was found to be too enlarged as in untreated rheumatic heart valve disease.

Not considering those cases of hyperthyroidism which have not been evaluated, the results of therapy with either amiodarone or electrical DC countershock seemed to be equally effective, no matter what the etiology of the fibrillation was.

In spite of the chemical composition of amiodarone, which has 2 iodine atoms and is remarkably similar to thyroxine, Pritchard et al (1975) have indicated it as the mainstay of treatment of atrial fibrillation due to thyrotoxicosis. These authors have evaluated the behaviour of hormonal levels in patients submitted to amiodarone therapy and came to the conclusion that serum levels of $T_{1}$ and PBI were significantly raised while $T_{3}$ was lowered, $T_{4} / T_{3}$ rate was considerably increased and TSH levels been normal in all but one case. These facts could be explained by the presence of iodine in amiodarone molecule or preferential $\mathrm{T}_{4}$ thyroidal synthesis associated to diminished peripheral rate of $\mathrm{T}_{4}$ conversion into $\mathrm{T}_{3}$. According to these authors the drug would act by blocking endogenous thyroxine in the heart or by limiting its metabolism in thyroxine-dependent reactions. 
It had been already decided to exclude the cases of hyperthyroidism from this experiment when the afore mentioned work was published. Though the exposed argumentation has been accepted it seems difficult to ignore the cases of hyperthyroidism warsened by amiodarone (Massin et al 1971, Chapelle et al 1976) as well as the cases of hypofunction provoked by too high maintenance doses.

In our casuistry referred in this paper, only 2 out of 80 patients presented minor signs or symptoms sugestive of hypofunction. In a group of other patients treated with amiodarone which have been observed aside this experiment, only one mixoedema that promptly reverted when the drug was withdrawn has been reported.

The most impressive side effect of this drug was the presence of micro-deposits almost constantly observed in patients submitted to long standing treatment, which could be related to the iodine containing molecule. The corneal opocification is included in a group where Fleischer's verticillate cornea and anti-malarian drug related corneal mico-deposits have been described. These are small yellowish opacities arranged along winding strands that converge to a paracentric infero-internal spot, like the magnetic field lines. Three types have been described according to the intensity of its presence, from only one or two lines, first unilaterally then bilaterally, up to the 3rd degree, where verticillate cornea aspect is attained. Like other iodinated substances, amiodarone is excreted by the lacrimal gland and is deposited directly, or as a metabolite, in the most superficial layers of the lower third of the cornea, in relation to the superior rim of the lower eyelid which, by adhering to the eyeball, forms a pavement for the deposit. Its detection can only be achieved by means of biomicroscopy, which results in its use for observing patients treated with amiodarone.

As far as we know, all corneal lesions related to the use of this drug have been reversible and in all our patients withdrawal of amiodarone was sufficient for disappearance of the corneal lesions to be effective, permiting in some cases going back to treatment although with lower doses. Though more frequent in patients submitted to long term therapy, cases not dose dependent have been reported.

Considering the similarity to anti-malarian drug intoxication, changes in the macular zone have been systematically looked for, but only in a few cases descrite incharacteristic pigmentar lesions could be found.

As afore mentioned all our cases with ocular changes promptly reverted when the drug was discontinued. The efficacy of topical use of sodium iodoheparinate or methylcellulose colirium has been reported though it has not yet been tested by us.

Concomitantly, some cases of photodermatosis accompanied by cutaneous rash in the light exposed zones, have been described in $10 \%$ of the patients treated with amiodarone.

In sharp contrast with the constancy of corneal alterations, no evidence of cutaneous lesion has ever been found in any patient, which could be explained by the low maintenance doses employed. When higher doses of amiodarone were used in order to control coronary insufficiency, cutaneous deposits and photodermatosis would be a frequent finding. However, some predisposed patients could present early cutaneous lesions as Rosenbaum et al (1976) have described in a patient who developed erythema nodosium with a low dose of amiodarone similar to that which has been used by us.

Of particular interest have been the effects of amiodarone on cardiac dromotropism and excitability, leading to increased refractory period and lenght of monophasic action potencial (William 1970) and diminished conductivity (Facquet et al 1970). These 
properties have been responsible for the beneficial or harmful drug effects we have just considered.

Among our patients, one has presented AV Wenckebach'block, reversible when therapy was discontinued, but we also had once the opportunity to see in a patient with Stokes-Adams crisis referred to us for implanting pacemaker who had been taking $600 \mathrm{mg}$ of amiodarone daily for over 3 months. In this case the problem was solved when therapy was withdrawn. Several cases described in literature (Alboni et al 1973. Rosenbaum et al 1976) belong probably to the same type and are related to the amount of drug impregnation. The electrocardiogram shows peculiar aspects of impregnation and also precocious, non-specific ST depression and more characteristically, rounded, sometimes bifid $T$ waves have been recorded.

The anomaly of conductivity is predominantly intraventricular and expressed by an increased length of QT, although no patient was reported to have bundle branch block. Only in the late course of therapy have sinoatrial, intra-atrial or atriventricular alterations been reported.

If can be therefore concluded that the results of therapy with amiodarone as a cardioverter have been by all means similar to those reported for the treatment with direct current countershock and that innocuity has also been comparable.

The simple requirements of chemical cardioversion, in sharp contrast to the complex procedures inherent to the use of DC countershock (sophisticated machinery, narco-analgesy and monitorized survey for some hours) has brought amiodarone to the first rank when conversion of atrial fibrillation into sinus rhythm is required.

\section{RESUMO}

A amiodarona, electrofisiologicamente capaz de aumentar a duração do potencial monofásico, foi utilizada para tratar 80 doentes com fibrilhação auricular estável. Em 88 tratamentos, obtiveram-se 75 conversões a ritmo sinusal (86\%). Verificou-se uma taxa de reversão à fibrilhação baixa, pois de 44 doentes revistos ao fim de 1 ano, 32 persistiam em ritmo sinusal $(72 \%)$. Os insucessos terapêuticos foram relacionados com a existência de aurículas dilatadas.

Dos efeitos acessórios verificados, reversíveis, foram destacadas as lesões corneanas, as alteraçōes hormonais $e$ as repercussōes sobre a condução auriculoventricular e intraventricular.

Comparando com os resultados obtidos com a cardioversão eléctrica, conclui-se pela vantagem do fármaco, pela igual eficácia e inocuidade, e pela maior facilidade de realização da conversão química.

\section{REFERENCES}

ALBONI P, FISCHER DM: Bloco seno-atriale in corso di terapia con amiodarone. Gion lta Card 3: 288, 1973.

CHAPELLE M, NAOURI R, WOLFF F: l'hyperthyroidie à l'amiodarone: a propos de quatre observations cliniques. Arch Mal Coeur 69: 1073, 1976.

COELHO E, LUIS A SALES, PEREIRA L, COITO A: La conversion de la fibrillation auriculaire au rythme sinusal au moyen du courant continu (Êtude des premiers 50 cas). Actual Cardiol Angeiol Int 13: 167, 1964.

FACQUET J, NIVET M, GROSGOGEAT Y, et al: L'influence de l'amiodarone sur rythme cardiaque et l'électrocardiograme. Therapie 25: 335, 1970. 
HAZARD J, PERLEMUTER L, BERNHEIM R, GUILHAUME B, RICHIER D: Insuffisances thyroidiennes secondaires à un traitement par l'amiodarone. Pressé Med 2: 691, 1973.

HOLZMAN D, BROWN MG: The use of quinidine in established auricular fibrillation and flutter. Am J Med Ssi 222: 644, 1951.

LEFEVRE M, CRAMER J: Etude clinique de lamiodarone dans le traitment des troubles du rhythme cardiaque. Arch Méd Normandie 70: 45, 1975.

I.OWN B, AMARASINGHAM R, NEUMAN J, BERKOVITS BV: The use of synchronized direct current countershok in the treatment of cardiac arrhytmias. I Clin Invest 41: 1381, 1962.

I.Uî́ A SALES: A cardioversão eléctrica - Lição à escolha no Concurso para Professor Extraordinário de Medicina Interna da Faculdade de Medicina de Lisboa, 1973.

I.UÍS A SALES, COITO A, COELHO E: Tratamento da fibrilhaçāo auricular pur chuque eléctrico externo.J. Médico 54: 569, 1964.

MASSIN JP, THOMOPOULOS P, KARAM J, SAVOIE JC: Le risque thyroidien d'un nouveau coronaro-dilatateur iodé: l'amiodarone. Ann Endocrinol 32: 437, 1971.

MORAND P, BENATRE J, VLAU G, et al: Etude Clinique histologique (ultraestruture) de la pigmentation par le chlorhydrate d'amiodarone. Sem Hop Paris 48: 553, 1972.

OLSSON SB, BRORSON I., VARNAUSKAS E: Class 3 antiarrhythmic action in man. Observations from monophasic action potencial recordings and amiodarone treatment. Br Heart $J$ 35: 1255.1973.

PERNOD J, KERMAREC J: Intérêt de l'amiodarone dans le traitement des affections coronariennes. Vie Med Can Fr l: 103, 1971.

PRITCHARD DA, SINGH BN, HUSLEY PJ: Effects of amiodarone on thyroid function in patients with ischaemic heart disease. $\operatorname{Br}$ Heart $J$ 37: 856, 1975.

ROSENBAUM MB, CHIAIE PA, RYBA D, ELIZARI MV: Control of tachyarrhythmias associated with W'olff-Purkinson-White syndrome by amiodarone hydrochloride. Am I Cardiol 34: $215,1974$.

ROSENBAUM MB, CHIALE PA, HALPERN MS, NAU GJ, PRZYBYLSKI J, LEVI RJ, LAZZARI

JO, ELIZARI MV: Clinical efficacy of amiodarone as an antiarrbytmic agent. Am $J$ Cardiol 38: 934. 1976.

VASTESAEGER MM, GILLOT PH, VAN DER STRAETEN P: L'effect anti -arythmique de l'amiodarone. Brwx Med S1: 99, 1971.

VERIN PH, GENDRE PH, BARCHEWITZ G, et al: Thésaurismose cornéenne par amiodarone. Données récentes. Arch Opbtalmol 31: 581, 1971.

WILLIAMS EM, VAUGHAN: Classification of anti-arrhythmic drugs. In, Symposium on Cardiac Arrhythmias (SANDOE E, FIENSTED-JESEN E, OLENSEN KH, ed) Södertälje, Sweden, AB Astra. p. 449. 1970.

Adress for reprints: A. Lema Santos

Department of Medicinc I

Faculiy of Medical Science:

Egar Moniz Hospital

Lisbon - Portugal 


\section{Messiedrs,}

Avant de vous parler des malades de notre service, j'ai besoin de bien vous dire ce que j'entends par un enseignement clinique, ce que doit être un professeur, ce que doivent être ceux qui suivent ses leçons. - Il m'est sans doule agréable de voir de nombreux élèves se presser autour des lits et remplir les bancs de l'amphithéâtre; mais il m'est bien plus agréable encore d'avoir la conscience de remplir une utile mission, et de laisser dans l'esprit de la jeunesse des notions qui seront fécondées plus tard. Du côté du professeur, du côté des élèves qui viennent l'entendre, il y a certaines condilions sans lesquelles un enseignement clinique est nécessairement stérile.

Bien que la clinique soit le couronnement des études médicales, cependant, messieurs, je ne voudrais pas vous laisser croire que cette élude ne doit être commencée que lorsque vous êtes bienttôt arrivés au terme de votre carrière d'étudiants.

Du jour qu'un jeune homme doil être médecin, il doit fréquenter les hôpitaux. Il faut voir, toujours voir des malades. Ces matériaux confus, que Pon amasse sans ordre et sans méthode, sont pourtant d'excellents matériaux; inutiles aujourd'hui, vous les retrouverez plus tard enfouis dans les trésors de votre mémoire. Arrivé aujourd'hui à la vieillesse, je me rappelle les malades que j'ai vus il y a quarante-trois ans, lorsque je faisais les premiers pas dans la carrière; je me rappelle les principaux symptômes, les lésions anatomiques, les numéros des lits, quelquefois les noms des malades qui, à cette époque si éloignée, ont frappé mon esprit. Ces souvenirs me servent souvent, ils m'instruisent encore, et quelquefois vous m'entendez les invoquer dans nos conférences cliniques.

Je demande donc que le jeune étudiant assiste tous les jours à une visite d'hôpital. Il importe peu pour moi qu'il commence par trousseau, Clinique.

$$
\text { 1. }-1
$$

\section{CLINIQUE MÉDICALE}

\section{L'HOTEL-DIEU DE PARIS}

TOME PREMIER

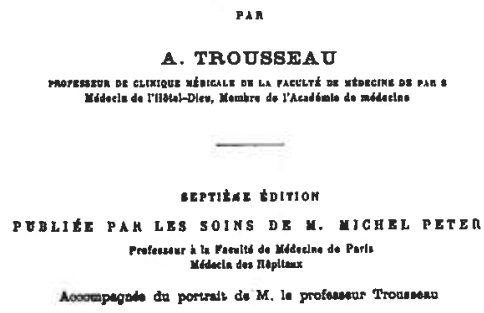

PARIS

LIBRAIRIE J.-B. BAILLIERE ET FILS

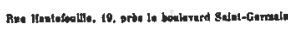
1885

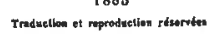

